We conclude that non-A, non-B hepatitis after blood transfusion from a largely British blood donor group probably leads to clinically significant chronic liver disease very rarely indeed.

We thank Dr A J Cassels-Smith (clinical biochemistry) and Dr A J Watson (histopathology) together with members of the medical staff of the Cardiothoracic Centre. Thanks are also due to Mrs A Asch for secretarial work. The study was funded by the Newcastle upon Tyne DHA Research Committee.

\section{References}

${ }^{1}$ Medical Research Council Working Party on Post-transfusion Hepatitis. Post-transfusion hepatitis in a London hospital: results of a two-year prospective study. $\mathcal{F}$ Hyg (Camb) 1974;73:173-88.

${ }^{2}$ Alter HJ, Purcell RH, Holland PV, Feinstone SM, Morrou AG, Moritsugu Y. Clinical and serological analysis of transfusion-associated hepatitis. Lancet 1975 ;ii :838-41.

${ }^{3}$ Knodell RG, Conrad ME, Ginsberg AL, Bell CJ. Efficacy of prophylactic gamma-globulin in preventing non A non B post-transfusion hepatitis. Lancet 1976; i:557-61.

4 Tremolada F, Chiappetta F, Noventa F, Valfre C, Ongaro G, Realdi G. Prospective study of post-transfusion hepatitis in cardiac surgery patients receiving only blood or blood products. Vox Sang 1983;44: 25-30.

${ }^{5}$ Grillner L, Bergdahl S, Jyrala A. Non-A, non-B hepatitis after open-heart surgery in Sweden. Scand F Infect Dis 1982;14:171-5.

${ }^{6}$ Togo T, Abe Y, Kagawa Y, Horiuchi T, Fukao A, Suzuki B. A study of Tा non A non $B$ hepatitis after open-heart surgery. Fapanese fournal of $\varrho$ Thoracic Surgery $1981 ; 34: 604-8$.

${ }^{7}$ Shimizu JK, Feinstone SM, Purcell RH, Alter HJ, London WT. Non A $\overline{\bar{F}}$ non B hepatitis: ultrastructural evidence for two agents in experimentally infected chimpanzees. Science 1979;205:197-200.

${ }^{8}$ Craske J, Spooner RJD, Van der Velde EM. Evidence for existence of at least two types of factor VIII associated non B transfusion hepatitis. Lancet 1978;ii:1051-2.

${ }^{9}$ Fletcher M, Trowell J, Craske J, Rizza CR. Non A non B hepatitis after factor VIII replacement. Gut 1983;24:A484-5.

10 Katchaki JN, Siem TH, Brower R, Van Loon AM, Van Der Logt JThM. Post-transfusion non A non B hepatitis in the Netherlands. $\mathrm{Br} \mathrm{Med} \mathrm{f}$ 1981 ;282:107-8.

(Accepted 26 August 1983)

\title{
Chloramphenicol toxicity in neonates: its incidence and prevention
}

\author{
ANNE MULHALL, JOHN DE LOUVOIS, ROSALINDE HURLEY
}

\begin{abstract}
The incidence of dose related chloramphenicol toxicity was determined in 64 neonates from 12 hospitals. Ten of the 64 exhibited symptoms attributed clinically to chloramphenicol toxicity. Nine received the dose prescribed and one an overdose. Symptoms of the grey baby syndrome were observed in five of the 10 babies; four babies suffered reversible haematological reactions; and one baby was described as very grey. Peak serum chloramphenicol concentrations in these 10 babies ranged from 28 to $180 \mathrm{mg} / 1$ and trough concentrations from 19 to $47 \mathrm{mg} / 1$. Serum chloramphenicol concentrations above the therapeutic range $(15-25 \mathrm{mg} / \mathrm{l})$ were observed in a further 27 neonates (two had received a 10-fold overdose), none of whom showed signs of toxicity.

Serious toxicity was associated with either prescription of dosages greater than that recommended or overdosage of chloramphenicol. High concentrations in young neonates may be avoided by prescribing and giving the recommended dose and then careful monitoring; concentrations should be maintained between 15 and $25 \mathrm{mg} / 1$. No babies with concentrations within this range showed clinical signs of toxicity.
\end{abstract}

\section{Introduction}

Despite concern about its toxicity chloramphenicol is widely used to treat neonatal meningitis. ${ }^{1}$ Three types of toxicity

\footnotetext{
Queen Charlotte's Maternity Hospital and Institute of Obstetrics and Gynaecology, London W6 OXG

ANNE MULHALL, PHD, BSC, senior microbiologist

JOHN DE LOUVOIS, PHD, MRCPATH, principal microbiologist

ROSALINDE HURLEY, MD, FRCPATH, professor of microbiology

Correspondence to: Dr A Mulhall.
}

have been described-namely, the grey baby syndrome, ${ }^{2}$ reversible dose related haemopoietic disturbances, ${ }^{3}$ and idio- $\infty$ pathic marrow aplasia unrelated to dosage. ${ }^{4}$ Serum chloramphenicol concentrations between 40 and $200 \mathrm{mg} / \mathrm{l}$ have been reported in association with the grey syndrome, ${ }^{56}$ and reversible bone marrow suppression related to dosage may occur when serum concentrations exceed $25 \mathrm{mg} / \mathrm{l.}^{3}$ Irreversible marrow aplasia is a rare complication (incidence $1 / 20000$ to $1 / 80000$ patients treated) and has a high mortality. Its occurrence is unpredictable.

The incidence of dose related chloramphenicol toxicity in the $\bar{\partial}$ newborn is unknown. There is no general agreement on the desirable therapeutic range of chloramphenicol concentrations, but serum concentrations of $10-20 \mathrm{mg} / 1^{7}$ and $15-25 \mathrm{mg} / 1^{8}$ are often quoted. As the minimum inhibitory concentration of chloramphenicol for some Gram negative rods may be as high 3 as $6 \mathrm{mg} / \mathrm{l}$ and only $30-60 \%$ of the drug crosses the meninges it would seem more appropriate to maintain serum concentrations in the range $15-25 \mathrm{mg} / \mathrm{l}$ provided that such concentrations are not associated with toxic manifestations.

In this study, which was carried out between March $1978 \mathrm{~N}$ and August 1981, we determined the incidence of dose related $D$ chloramphenicol toxicity in 64 neonates receiving chloram- 을 phenicol for life threatening infections. We assessed the value $\mathrm{N}$ of measuring serum concentrations of the drug and the pos- N sibility of predicting toxic effects and establishing the thera- $\sigma$ peutic range of chloramphenicol concentrations.

\section{Patients and methods}

Study population-We studied 64 neonates (less than 28 days old) $\stackrel{\vec{D}}{\vec{D}}$ from 12 hospitals who formed part of a larger study on the penetration $\frac{O}{D}$ of antibiotics in neonatal meningitis. ${ }^{19}$ Their gestational ages ranged $\unrhd$ from 26 to 40 weeks and their birth weights from 770 to $4420 \mathrm{~g}$. All the babies were scrutinised during treatment for signs and symptoms $?$ of the grey baby syndrome-that is, vomiting, respiratory distress, 응 abdominal distension, ashen grey cyanosis, flaccidity, and cardiovascular collapse. Adverse haematological reactions were also sought. $\frac{\bar{c}}{\bar{T}}$ 
Dosage and assay of chloramphenicol-The prescribed dosage of chloramphenicol and any subsequent adjustments were decided by the referring paediatricians. Chloramphenicol was administered intravenously on 91 occasions, intramuscularly on 14, and by mouth on 13. Concentrations of active chloramphenicol were determined in 205 timed specimens of serum by methods described elsewhere. ${ }^{10}$ Chloramphenicol esters and metabolites were not measured by this method. Opinion varies on the time to peak serum chloramphenicol concentration in the neonate ${ }^{811-13}$; in this study the term peak concentration applies to samples collected 15 minutes to one hour after intravenous administration, 30 minutes to two hours after intramuscular administration, and one to four hours after oral administration. Recommended doses were taken as $25 \mathrm{mg} / \mathrm{kg} /$ day for preterm and term babies in the first week of life and $37.5-50 \mathrm{mg} /$ $\mathrm{kg} /$ day for term babies older than seven days. ${ }^{14}$

\section{Results}

Ten of the 64 babies had symptoms that were attributed clinically to chloramphenicol toxicity. Nine received the prescribed dose, although in six this was greater than that recommended (table I). One baby received a 10 -fold overdose. Four of the nine babies collapsed suddenly, became grey, and suffered cardiac arrest within 48 hours after the first dose of chloramphenicol (table I). The drug was stopped in two of these four babies, one of whom gradually improved over the next 72 hours. The second remained stable for six hours but then rapidly deteriorated with cardiac and respiratory arrest and died. Postmortem examination showed an intraventricular haemorrhage. Dosage was reduced in the other two neonates. One showed a rapid deterioration, developed disseminated intravascular coagulation, and suffered several fits; he survived, but with neurological sequelae. The other, who had $E$ coli meningitis, died three days later. Four babies developed adverse haematological reactions three to 10 days after the start of treatment, thrombocytopenia developing in three and neutropenia in one. Haematological values in all four returned to normal after chloramphenicol treatment was reduced or stopped. The last baby was described as very grey after 14 days' treatment, and the antibiotic was stopped. Serum concentrations at this time were within the range $15-25 \mathrm{mg} / \mathrm{l}$, although previous concentrations had been high. Peak serum chloramphenicol concentrations in the nine babies exhibiting toxic symptoms ranged from 28 to $140 \mathrm{mg} / \mathrm{l}$, and trough concentrations were in the range 19 to $47 \mathrm{mg} / \mathrm{l}$.

Four accidents regarding the use of chloramphenicol were recorded. A 10-fold overdose was administered to three babies. For the first neonate $13.3 \mathrm{mg} / \mathrm{kg}$ every six hours $(53 \mathrm{mg} / \mathrm{kg} /$ day $)$ was prescribed, and the baby received 10 times this amount on two occasions. A serum concentration of $180 \mathrm{mg} / \mathrm{l}$ was recorded six hours after the second overdose, and his condition rapidly deteriorated with appreciable bradycardia and no urine output. He received two exchange transfusions, but the serum concentration was still high at $51 \mathrm{mg} / \mathrm{l}$, and cardiac arrest and death ensued 31 hours after the second overdose. Cause of death was recorded as acute suppurative encephalitis and chloramphenicol toxicity. The figure shows the effects of the two exchange transfusions on serum chloramphenicol concentrations.

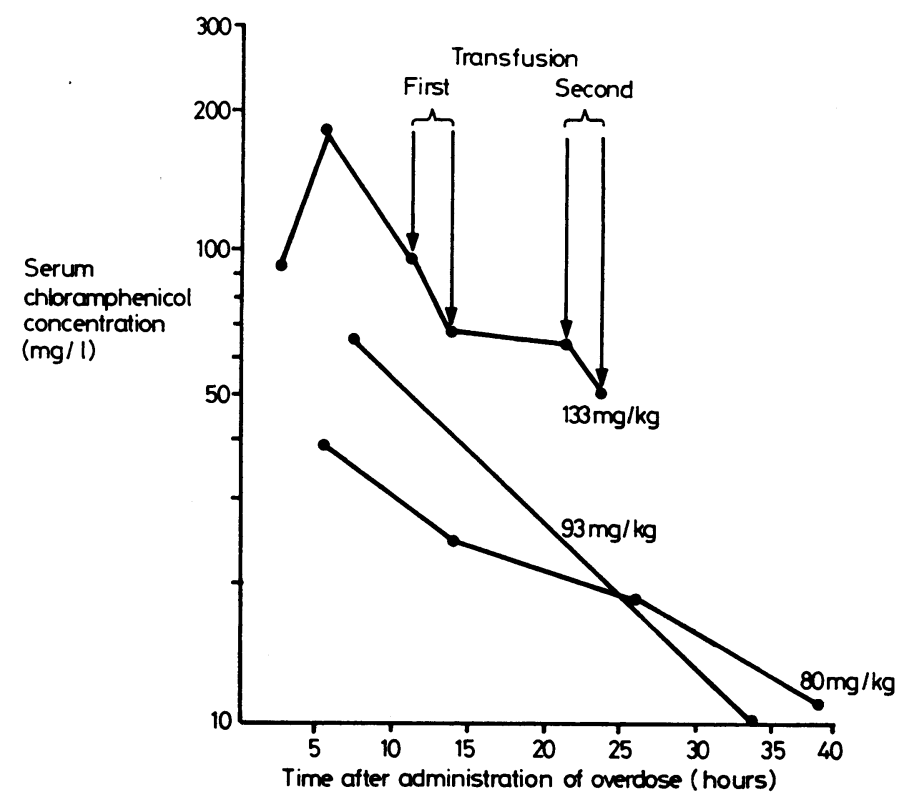

Serum chloramphenicol concentrations over time, and dosages administered, in three babies who received overdoses.

The second baby, for whom $9.3 \mathrm{mg} / \mathrm{kg}$ every six hours $(37 \mathrm{mg} / \mathrm{kg} /$ day) was prescribed, showed no symptoms of toxicity despite having a serum concentration of $65 \mathrm{mg} / \mathrm{l}$ seven and a half hours after the overdose. The remaining neonate (prescribed dose $24 \mathrm{mg} / \mathrm{kg} /$ day) received a dose of $80 \mathrm{mg} / \mathrm{kg}$. The only adverse effect was acidosis, and after $\mathbf{4 0}$ hours treatment was restarted. Blood chloramphenicol concentration five hours after the overdose was $40 \mathrm{mg} / \mathrm{l}$. Serum chloramphenicol concentrations below $25 \mathrm{mg} / 1$ were recorded in both these latter babies within 14-22 hours. The figure shows the concentration time curves in these three neonates. One baby received $40 \mathrm{mg}$

TABLE I-Signs of toxicity in nine neonates receiving chloramphenicol

\begin{tabular}{|c|c|c|c|c|c|}
\hline Case No & Evidence of toxicity & $\begin{array}{c}\text { Dose } \\
\text { (mg/kg/day) }\end{array}$ & $\begin{array}{l}\text { Recommended dose }{ }^{14} \\
(\mathrm{mg} / \mathrm{kg} / \text { day })\end{array}$ & $\begin{array}{c}\text { Serum concentration } \\
(\mathrm{mg} / \mathrm{l})\end{array}$ & $\begin{array}{c}\text { Time after dose } \\
\text { (hours) }\end{array}$ \\
\hline 1 & Sudden collapse, grey coloration, cardiac and respiratory difficulties & $\int 34$ & 25 & $\begin{array}{r}>38 \\
>80 \\
4\end{array}$ & $\begin{array}{l}4 \cdot 5 \\
25 \\
92\end{array}$ \\
\hline 2 & Sudden collapse, grey coloration, cardiac and respiratory difficulties & 53 & 25 & 35 & 2 \\
\hline 3 & Sudden collapse, grey coloration, cardiac and respiratory difficulties & $\left\{\begin{array}{l}77 \\
77 \\
41\end{array}\right.$ & 25 & $\begin{array}{c}>60 \\
140^{*} \\
124^{*} \\
90\end{array}$ & $\begin{array}{l}7 \cdot 5 \\
5^{*} \\
7 \cdot 5^{*} \\
7\end{array}$ \\
\hline 4 & Sudden collapse, grey coloration, cardiac and respiratory difficulties & $\left\{\begin{array}{l}50 \\
36 \\
36\end{array}\right.$ & 25 & $\begin{array}{r}31 \\
46 \\
35 \\
>43\end{array}$ & $\begin{array}{c}12 \\
0.5 \\
12 \\
6\end{array}$ \\
\hline 5 & Haematological & 22 & 25 & $\begin{array}{l}45 \\
36 \\
40\end{array}$ & $\begin{array}{r}1 \\
12 \\
1\end{array}$ \\
\hline 6 & Haematological & $\int 50$ & 25 & $\begin{array}{l}38 \\
47 \\
47\end{array}$ & $\begin{array}{r}12 \\
12 \\
12\end{array}$ \\
\hline 7 & Haematological & 25 & 25 & $\begin{array}{l}19 \\
34 \\
30 \\
56\end{array}$ & $\begin{array}{r}12 \\
1 \\
12 \\
1\end{array}$ \\
\hline 8 & Haematological & $\{37 \cdot 5$ & $37 \cdot 5-50$ & $\begin{array}{r}72 \\
100\end{array}$ & $\mathbf{1}$ \\
\hline 9 & Very grey & 29 & 25 & $\begin{array}{l}21 \\
28 \\
10\end{array}$ & $\begin{array}{c}12 \\
0.5 \\
24\end{array}$ \\
\hline
\end{tabular}

*Values before and after exchange transfusion. 
chloramphenicol intraventricularly instead of intravenously. The concentration of chloramphenicol in cerebrospinal fluid 18 hours later was $52 \mathrm{mg} / \mathrm{l}$, although the serum concentration at this time was only $3 \mathrm{mg} / \mathrm{l}$. The patient was lost to follow up.

High serum concentrations, which may have been the result of an unrecognised overdose, were observed in four babies. Two of these (cases 1 and 8 , table I) suffered toxic effects. The other two, who were prescribed 60 and $50 \mathrm{mg} / \mathrm{kg} /$ day (recommended dosage 37.5 and $25 \mathrm{mg} / \mathrm{kg} /$ day respectively), showed no signs of toxicity despite a peak concentration of $90 \mathrm{mg} / \mathrm{l}$ in one and a concentration of $31 \mathrm{mg} / 1$ 17 hours after injection in the other. The remaining 49 babies showed no obvious toxic signs or symptoms resulting from chloramphenicol treatment. Table II shows serum chloramphenicol concentrations and dosage schedules in $\mathbf{4 5}$ of these neonates; data from four babies could not be evaluated. Peak chloramphenicol concentrations $>25 \mathrm{mg} /$ 1 or trough concentrations $>15 \mathrm{mg} / \mathrm{l}$, or both, were observed in 23 of these neonates, 16 of whom were given more than the recommended dose. Three of these babies had concentrations greater than $50 \mathrm{mg} / \mathrm{l}$. Table III shows the relation between dosage, high serum concentrations, and toxicity.

The 10 babies who showed signs of chloramphenicol toxicity had normal renal function before treatment. During treatment oedema, hyponatraemia, and reduced urine output were recorded in four, two of whom were found later to have inappropriate secretion of antidiuretic hormone.

TABLE II-Dosage schedules and serum chloramphenicol concentrations in 45 neonates who did not show any signs of toxicity

\begin{tabular}{|c|c|c|c|c|}
\hline \multirow[b]{2}{*}{ Dosage given } & \multicolumn{3}{|c|}{ Serum chloramphenicol concentrations } & \multirow[b]{2}{*}{ Total } \\
\hline & Peak $<15 \mathrm{mg} / \mathrm{l}$ & $\begin{array}{l}\text { Peak } 15-25 \mathrm{mg} / 1 \\
\text { trough }<15 \mathrm{mg} / 1\end{array}$ & $\begin{array}{c}\text { Peak }>25 \mathrm{mg} / 1 \\
\text { trough }>15 \mathrm{mg} / 1\end{array}$ & \\
\hline $\begin{array}{l}\text { Recommended }^{14} \\
>\text { Recommended } \\
<\text { Recommended }\end{array}$ & $\begin{array}{l}4 \\
1 \\
9\end{array}$ & $\begin{array}{l}4 \\
3 \\
1\end{array}$ & $\begin{array}{r}3 \\
16 \\
4\end{array}$ & $\begin{array}{l}11 \\
20 \\
14\end{array}$ \\
\hline Total & 14 & 8 & 23 & 45 \\
\hline
\end{tabular}

TABLE III-Relation between dosage, high serum concentrations, and toxicity

\begin{tabular}{lrcc}
\hline & No & $\begin{array}{c}\text { Peak concentration }>25 \mathrm{mg} / 1 \\
\text { or trough }>15 \mathrm{mg} / \mathrm{l} \text { or both }\end{array}$ & $\begin{array}{c}\text { Clinical signs or } \\
\text { symptoms of toxicity }\end{array}$ \\
\hline Prescribed dose & 54 & 32 & $9^{*}$ \\
Known overdose & 4 & $3+1(\mathrm{CSF})$ & 1 \\
?Overdose & 2 & 2 & 10 \\
Not evaluated & 4 & $37+1(\mathrm{CSF})$ & \\
\hline Total & 64 & &
\end{tabular}

CSF $=$ Cerebrospinal fluid.

*All nine babies had peak concentrations $>25 \mathrm{mg} / 1$ or trough concentrations $>15 \mathrm{mg} / \mathrm{l}$, or both. In two cases an overdose was suspected.

\section{Discussion}

The present study has shown that many neonates (27/37) can tolerate serum chloramphenicol concentrations above $25 \mathrm{mg} / \mathrm{l}$ with no clinical signs of toxicity. Seven of these 27 babies had serum concentrations in excess of $50 \mathrm{mg} / \mathrm{l}$. No relation could be established between the duration of high serum concentrations and toxicity. The effect of high serum concentrations may be related to age, as nine of the 10 babies who showed toxic signs were less than nine days old while four of the seven with serum concentrations $>50 \mathrm{mg} / \mathrm{l}$ but no toxicity were more than 20 days old. High serum concentrations in the absence of toxicity have been reported in a 10 week old baby. ${ }^{15}$

Our results suggest that chloramphenicol may be used safely to treat neonates if serum concentrations are maintained in the range $15-25 \mathrm{mg} / \mathrm{l}$, as no babies with concentrations in this range showed signs of toxicity. Symptoms of the grey syndrome were associated with very high serum concentrations (35$180 \mathrm{mg} / \mathrm{l}$ ), which are unlikely to occur unless an overdose has been administered or the prescribed dosage is well above that recommended. Reversible haematological side effects occurred at lower serum concentrations, which were nevertheless outside the therapeutic range, and were not associated with prolonged treatment. Predicting those at risk of haematological effects is difficult.

The delayed clearance of chloramphenicol in neonates is thought to be due to inefficient glucuronidisation in the liver and reduced renal elimination of the metabolite. ${ }^{16}$ Poor renal function would result in both reduced elimination of active chloramphenicol by glomerular filtration and reduced elimination of the parent ester, which would remain in the body and subsequently undergo hydrolysis to active drug. Our results indicate that one manifestation of the grey syndrome is reduced renal output resulting in persistent high serum concentrations. Probably poor renal function is just as important as low activities of liver enzymes in maintaining high chloramphenicol concentrations.

The assertion that active chloramphenicol, rather than the parent compound or its metabolites, causes toxicity in the neonate is widely accepted but is based on indirect evidence. Adult patients with anuria accumulate high concentrations of glucuronide metabolite with no evidence of toxicity, ${ }^{17}$ and large doses of chloramphenicol glucuronide have been administered to rats without toxic reactions. Chloramphenicol glucuronide concentrations in neonates have not been determined.

Tenfold overdoses administered to three babies in this study were the result of the decimal point being misread when the injections were drawn up from a $1.2 \mathrm{~g}$ phial $(100 \mathrm{~g} / 1)$. When such a concentrated solution is used unrealistically small volumes are required for six hourly administration to small babies; a $300 \mathrm{mg}$ paediatric preparation is now available. The severity of the symptoms suffered by the three babies correlated with the measured concentrations of chloramphenicol in their blood. Young neonates are capable of withstanding and surviving high concentrations of chloramphenicol for short periods, although if excessively high concentrations persist death may result.

Multiple exchange transfusions have been advocated as effective treatment for severe chloramphenicol intoxication, ${ }^{18}$ but two exchange transfusions in one subject in the present study (figure) had little effect on serum chloramphenicol concentrations. Charcoal column haemoperfusion has been used with dramatic effect in one term neonate, reducing serum concentrations from $98 \mathrm{mg} / 1$ to $13.5 \mathrm{mg} / 1$ in three hours, but this treatment may have side effects. ${ }^{19}$

In the present study serious toxicity was associated with either overprescription or overdosage of chloramphenicol in most cases. Thus high serum chloramphenicol concentrations and their associated toxicity in young neonates may be avoided by prescribing the recommended dose initially ${ }^{14}$ and then monitoring blood concentrations and haematological values every 48 hours. The microbiological method used in this study is within the competence of any routine clinical laboratory and yields results in five hours. Particular attention should be paid to babies with poor renal and liver function, and extreme care must be exercised to avoid arithmetic errors when preparing injections.

We thank the paediatricians at the following hospitals for allowing us to study their patients and for providing the clinical information contained in this paper, and the microbiologists for their support: Bromley Hospital, Bromley; Farnborough Hospital, Orpington; Hammersmith Hospital, London; Horton General Hospital, Banbury; John Radcliffe Hospital, Oxford; King's College Hospital, London; Lewisham Hospital, London; Northwick Park Hospital, Harrow; Queen Charlotte's Maternity Hospital, London; Queen Elizabeth's Hospital for Sick Children, London; St Helier Hospital, Carshalton; and the Hospital for Sick Children, London.

\section{References}

${ }^{1}$ Mulhall A, de Louvois J, Hurley R. The efficacy of chloramphenicol in the treatment of neonatal and infantile meningitis; a study of 70 cases. Lancet 1983;i :284-7. 
2 Sutherland JM. Fatal cardiovascular collapse of infants receiving large amounts of chloramphenicol. Am $\mathcal{F}$ Dis Child 1959;97:761-7.

${ }^{3}$ Scott JL, Finegold SM, Belkin GA, Lawrence JS. A controlled double blind study of the haematologic toxicity of chloramphenicol. $N$ Engl f Med $1965 ; 272: 1137-42$.

4 Yunis AA, Bloomberg GR. Chloramphenicol toxicity: clinical features and pathogenesis. Prog Hematol 1964;4:138.

${ }^{5}$ Craft AW, Brocklebank JT, Hey EN, Jackson RH. The "grey-toddler." Chloramphenicol toxicity. Arch Dis Child 1974;49:235-7.

${ }^{6}$ Slaughter RL, Pieper JA, Cerra FB, Brodsky B, Koup JR. Chloramphenicol sodium succinate kinetics in critically ill patients. Clin Pharmacol Ther $1980 ; 28: 69-77$.

${ }^{7}$ Lietman PS. Chloramphenicol and the neonate; 1979 view. Clin Perinatol $1979 ; 6: 151-62$.

${ }^{8}$ Glazer JP, Danish MA, Plotkin SA, Yaffe JS. Disposition of chloramphenicol in low birthweight infants. Pediatrics 1980;66:573-8.

${ }^{9}$ Mulhall A. Antibiotic treatment in the newborn: some pharmacological aspects. London: University of London, 1982. PhD thesis.

10 de Louvois J. Factors influencing the assay of antimicrobial drugs in clinical samples by the agar plate diffusion method. $\mathcal{F}$ Antimicrob Chemother 1982;9:253-65.

" Nishimura T, Kotani Y. Special characteristics of absorption and excretion of chloramphenicol in premature and newborn infants. Bull Osaka Med Sch 1970;16:169-81.

12 Pickering LK, Hoeker JL, Kramer WG, Kohl S, Cleary TG. Clinical pharmacology of two chloramphenicol preparations in children: sodium succinate (iv) and palmitate (oral) esters. $\mathcal{f}$ Pediatr 1980;96: 757-61.

${ }^{13}$ Rajchgot P, Prober CG, Soldin S, et al. Initiation of chloramphenicol therapy in the newborn infant. $\mathcal{F}$ Pediatr 1982;101:1018-21.

14 Reynolds JEF, ed. Martindale. The extra pharmacopoeia. 28th ed. London: Pharmaceutical Press, 1982:1139.

${ }^{15}$ Stevens DC, Kleiman MB, Lietman PS, Schreiner RL. Exchange transfusion in acute chloramphenicol toxicity. F Pediatr 1981;99:651-3.

${ }^{16}$ Weiss CF, Glazko AJ, Weston JK. Chloramphenicol in the newborn infant. N Engl F Med 1960;262:787-94.

17 Kunin CM. A guide to use of antibiotics in patients with renal disease. Ann Intern Med 1967;67:151.

${ }^{18}$ Kessler DL Jr, Smith AL, Woodrum DE. Chloramphenicol toxicity in a neonate treated with exchange transfusion. F Pediatr 1980;96:140-1.

19 Mauer SM, Chavers BM, Kjellstrand CM. Treatment of an infant with severe chloramphenicol intoxication using charcoal column hemoperfusion. $\mathcal{F}$ Pediatr 1980;96:136-9.

(Accepted 9 September 1983)

\section{SHORT REPORTS}

\section{Do some marathon runners bleed into the gut?}

Bleeding into the bladder wall and exercise related haematuria are recognised complications of marathon running. ${ }^{1}$ Bleeding may also occur into the bowel ${ }^{2}$ and perhaps caecal wall. ${ }^{3}$ I report a study of runners in a provincial marathon race.

\section{Patients, methods, and results}

I posted questionnaires to the 600 runners who registered for the 1983 Guildford marathon. The questionnaires established the age, sex, number of previous marathons, weekly training milage, and the presence of gastrointestinal symptoms and blood in vomit, urine, and stools. Of the 600 runners 415 showed their intention to run the full marathon by entering the second circuit of the course, and 386 completed the race. Of the 415 (287 men and 12 women) $299(72 \%)$ returned their questionnaires. In a preliminary study three runners who had taken part in a different marathon and were not entered for the Guildford marathon submitted to a hospital laboratory stool specimen taken before and after the marathon race. One of these three runners (a slow veteran) gave positive results for melaena after the race, though not before. He later ran in another marathon and again these results became positive.

In this study $10 \%$ of the original applicants were randomly selected and asked to test their urine for the presence of blood immediately after the race with a reagent strip (Labstix) and to provide stool smears taken before and after the race to test for the presence of occult blood (Hema-Chek). Samples were returned by 36 runners (about $54 \%$ of those eligible). None of them reported frank haematuria, but two had reagent strips giving positive results. These, however, do not discriminate between red blood cells, haemoglobin from march haemoglobinuria, or myoglobin, which may be produced in quantity during vigorous exercise. ${ }^{4}$ Only one runner (a young slow man) reported tarry stools. Two men (one young and fast, and one a slow veteran) with negative test results for melaena before the race gave definitely positive results after it. A further man (young and fast) had a weakly positive smear after the race. None of the smears was positive before the race. One runner gave positive results with both the urine reagent strip and stool smear. None of the runners with a positive stool smear result admitted to piles.

\section{Comment}

Only one of the 299 runners studied noted a tarry stool, but three $(8 \%)$ of 39 (including those in the preliminary study) passed stools after racing which gave positive results for melaena. This suggests that unrecognised bleeding into the gut during a marathon is no uncommon. Contributory factors may include an unsuspected local cause such as piles, damage to intraabdominal hollow organs from repetitive impact of a free surface against a fixed surface such as has been described for the bladder, ${ }^{1}$ relative ischaemia of the gut wall caused by diversion of the splanchnic circulation, ${ }^{2}$ and trauma haemolysis in the feet which might trigger disseminated intravascular coagulation with some consumption of coagulation factors and cause a predisposition to bleeding. The aetiology of the mild anaemia found in some distance runners is obscure, ${ }^{5}$ but repeated oozing into the gut during training and racing may be a factor.

I thank the Guildford Lions and the marathon runners for their help and cooperation, Ames Ltd for diagnostic aids, and Dr J Shirley for advice. The study was financed by a grant from the research foundation of the Royal College of General Practitioners.

${ }^{1}$ Blacklock NJ. Bladder trauma in the long-distance runner: "10,000 metres haematuria." Br $\mathcal{F}$ Urol 1977;49:129-32.

2 Fogoros RN. "Runners' trots: gastrointestinal disturbances in runners," ҰAMA 1980;243:1743-4.

${ }^{3}$ Porter AMW. Marathon running and the caecal slap syndrome. $\mathrm{Br} f$ Sports Med 1982;16:178.

${ }^{4}$ Schiff HB, MacSearraigh ETM, Kallmeyer JC. Myoglobinuria, rhabdomyolysis and marathon running. $O \mathcal{F}$ Med 1978;47:463-72.

5 Samson D. What is "sports anaemia" ? Br Med f 1982;284:1685 and subsequent correspondence.

(Accepted 1 August 1983)

37 Upper Gordon Road, Camberley, Surrey

ALAN M W PORTER, MD, MRCGP, general practitioner

\section{Skin test wheal size and erythema not reduced by topical antihistamine}

Prior treatment with systemic antihistamine preparations suppresses pruritus induced by histamine ${ }^{1}$ and allergens ${ }^{2}$ and diminishes wheal size. ${ }^{3}$ It is common practice to apply a topical antihistamine preparation for symptomatic relief after skin testing with allergens, although the benefits of this have not been tested. We report a double blind controlled trial of mepyramine maleate cream versus placebo cream applied after skin testing in patients with atopy.

\section{Patients, methods, and results}

Skin prick tests were performed on both arms of 32 patients with atopy using the following Bencard allergens: house dust mite, grass and tree pollen, cat and dog fur, feathers, and aspergillus; positive (histamine) and negative controls were also used. After 10 minutes we recorded the diameter in millimetres of the largest wheal and the intensity of erythema on a visual analogue scale ranging fron "no erythema" to "intense erythema" on a 100 